\title{
Implementation of Learning with the Team Quiz Method to Improve Student Learning Outcomes in Mathematics in Classes IX SMP Negeri 1 Pulau Rakyat Asahan
}

\author{
Selamat Karo-Karo ${ }^{1} \quad$ Fransiskus Gultom ${ }^{1}$ dan Sanggam P. Gultom ${ }^{2}$ \\ 1.Darma Agung University Medan, Indonesia \\ 2.HKBP Nommensen University Medan, Indonesia
}

\begin{abstract}
This study aims to determine the application of the team quiz learning method to improve student learning outcomes on the congruence and likeness material in class IX SMP Negeri 1 Pulau Rakyat Asahan. The type of research used in this research is classroom action research using descriptive qualitative data analysis, with a total of 37 students as subjects. The data collection technique in this study was carried out based on 3 ways, namely tests, observation and documentation, the data from the observation and documentation tests were obtained through descriptive qualitative data analysis with data analysis techniques 1). Data reduction 2). Distribution, and 3). Draw conclusions. From the results of the research and discussion, it was obtained: 1) In the pre-cycle, the poor category with a score (21-40) was obtained by 21 students $(56.76 \%)$, and the good enough category with a score (41-60) was obtained as many as 16 students $(43.24 \%)$; 2 . In Cycle I, the unfavorable category with scores $(21-40)$ was obtained by 6 students $(16.22 \%)$, the category was quite good with scores (41-60) obtained by 18 students (48.65\%), good category with scores (61-80) obtained by 7 students (18.92\%), and very good categories with scores (81-100) obtained by 6 students (16.22\%); 3) In Cycle II, the good category with a score (61-80) was obtained by 15 students $(40.54 \%)$ and the very good category with a score (81-100) was obtained as many as 22 students $(59.46 \%)$.
\end{abstract}

Keywords: Team quiz method, student learning outcomes, congruence and congruence

DOI: $10.7176 / \mathrm{JEP} / 12-14-05$

Publication date:May $31^{\text {st }} 2021$

\section{Introduction}

Education is the main need of every human being, where one of the standards for the development of a country is the level of education of its population. Education in Law No. 20 of 2003 concerning the national education system is defined as a conscious and planned effort to create an atmosphere of learning and the learning process so that students actively develop their potential to have religious spiritual strength, self-control, personality, competence, noble morals, and skills needed by him, the people of the nation and the state. While the function of national education in Law no. 20 of 2003 concerning the national education system in article 3 states that national education functions to develop capabilities and shape a dignified national character and civilization in order to educate the nation's life, aiming at developing the potential of students to become human beings who believe and fear God Almighty, with noble character, healthy, knowledgeable, capable, creative, independent, and become democratic and responsible citizens.

Education is also an effort to develop the potential of students in a learning process in order to create quality individuals. This can be triggered by providing motivation to students and facilitating all their needs related to education, because every learning process requires abilities that can increase academic potential, especially in the learning outcomes of each student.

Educational goals are a description of the final position or values to be achieved from an educational process. As the goal of the level of education also lays the foundation of intelligence, knowledge, personality, noble character and skills to live independently and follow further education.

The aim of education is the perfection of human life so that it can fulfill all the physical and mental needs obtained from the nature of nature. The implementation is carried out in the usual way that is done by a teacher when teaching, namely by doing preliminaries because the beginning of a meeting in learning, which is aimed at improving student learning outcomes in the learning process. Then enter the core activities where starting to deliver material based on basic competencies, by means of learning methods that will be carried out. After that the child can observe, ask, explore, associate, communicate, and finally do the closing on learning (Hamimah, et al., 2019).

The abilities expected in education to improve learning outcomes include: 1) Cognitive abilities in children which include mental activities, where everything related to mental activities is included in cognitive; 2) Affective ability in children is related to attitudes and values, affective includes behavioral characteristics such as feelings, interests, attitudes, emotions, and values; and 3) Psychomotor abilities in children are related to the skills or abilities to act after a person has received a certain learning experience. 
The success of students also affects the method or method of learning carried out by educators. As stated by Wulandari, et al., (2017), so that students can learn well, teaching methods must be endeavored to be permanent, efficient and effective. Therefore, an educator must determine the learning method before learning begins and of course according to the material to be taught. By choosing the right learning method, students are able to absorb the learning provided by the teacher in the classroom.

The unattainable student learning outcomes are also caused by educators still using conventional learning methods, so that it can trigger boredom in students. Given this situation, most of the students did something bad, namely cheating with each other. This is due to the lack of interest of educators in using learning media which is also a trigger so that many students are less enthusiastic in participating in learning.

It was found that there were student problems related to learning outcomes, one of which was that there were still many students who got poor grades during semester tests. Therefore a solution to the above problems is needed, the researcher carries out research to implement an attractive learning method for students in helping the learning process so that learning outcomes can increase.

The active learning procedure uses the Time Quiz method, where the teacher chooses the topics presented in three categories, then the students are divided into three large groups. The Team Quiz method is a learning method that encourages students to be more active in class. Besides students being more active in learning, it also makes it easier to absorb the learning provided by the teacher.

Based on the above, due to the lack of willingness of children to learn and learning outcomes in children partially decreased, such as children who do not want to learn because they are engrossed in playing with their friends and disturbing friends who want to learn. Therefore, the researcher conducted a study entitled "Implementation of Learning with the Team Quiz Method to Improve Student Learning Outcomes in Mathematics in Class IX of SMP Negeri 1 Pulau Rakyat Asahan".

\section{Research Methods}

This research is a classroom action research conducted in collaboration with classroom teachers through selfreflection, with the aim of improving their performance as a teacher, so that student learning outcomes increase. Classroom action research is defined as an effort or action taken by the teacher or researcher to solve learning problems through research.

This research was conducted in class IX SMP Negeri 1 Pulau Rakyat Asahan. The subjects in this study were students of class IX in odd semesters, amounting to 37 students. This aims to see an increase in learning outcomes by applying the team quiz learning method Team Quiz.

Data collection in this study was carried out through: tests, observation and documentation. Researchers conducted tests by giving questions to students in the form of essays and group student rorksheets, then observing the classroom observations during learning, besides that, the documentation was carried out by collecting data such as: videos, photos during learning and learning media that has been made for the material to be delivered and along with RPP and others.

Data analysis is a continuation of the data collection stage. According to Kunandar (2012), in classroom action research there can be collected and analyzed, namely: qualitative data, namely data in the form of information in the form of sentences that provide an overview of student expressions related to the level of understanding of data related to categorization or characteristics in the form of properties that cannot be measured in size.

The data collected on each observation activity from the implementation of the classroom action research cycle were analyzed descriptively by using the percentage technique to see trends that occurred in learning activities. In learning outcomes by analyzing the average value of daily tests. Then categorized as very good, good, good enough, not good and not good.

Qualitative data analysis is related to student learning outcomes on the Congruence and Conformity material to determine the extent to which the increase in student learning outcomes occurs. Qualitative data analysis was in the form of data reduction, explanation and conclusion drawing. Thus the development and improvement of deficiencies can be carried out precisely on the aspect concerned.

\section{Results and Discussion \\ Results \\ Description Before the Cycle}

Classroom Action Research carried out on the material of Congruence and Likeness to students in class IX SMP Negeri 1 Pulau Rakyat Asahan. Oral formative tests to 37 students before the cycle obtained scores of student learning outcomes as in Table 1 below. 
Table 1. Data on Pre-Cycle Student Learning Outcomes

\begin{tabular}{|c|l|c|c|c|}
\hline No & Category & Score & Total Students & Percentage (\%) \\
\hline 1 & Very Good & $81-100$ & 0 & 0 \\
\hline 2 & Good & $61-80$ & 0 & 0 \\
\hline 3 & Pretty Good & $41-60$ & 16 & 43.24 \\
\hline 4 & Less Good & $21-40$ & 21 & 56.76 \\
\hline 5 & Not Good & $0-20$ & 0 & 0 \\
\hline \multicolumn{5}{|r}{ Amount } \\
\hline
\end{tabular}

Data source: Student Result Sheet before the Cycle

The percentage of the score obtained is still far from expectations, even though there are no students who get a score (0-20), but also no students get a score (61-80) and (81-100). Meanwhile, the students in the poor category with scores (21-40) were 21 people (56.76\%), while students in the good enough category with scores (41-60) were 16 people (43.24\%). Likewise, student participation or student behavior in class in the learning process is also not optimal. Preliminary observations with the aspect of observation include: student concentration, enthusiasm, responsibility, activeness in asking questions and the courage of students answering questions, the student participation score is obtained as in Table 2 below.

Table 2. Student Participation Data Before the Cycle

\begin{tabular}{|c|c|c|c|c|}
\hline No & Category & Score & Total Students & Percentage (\%) \\
\hline 1 & Very Good & $81-100$ & 0 & 0 \\
\hline 2 & Good & $61-80$ & 0 & 0 \\
\hline 3 & Pretty Good & $41-60$ & 16 & 43.24 \\
\hline 4 & Less Good & $21-40$ & 21 & 56.76 \\
\hline 5 & Not Good & $0-20$ & 0 & 0 \\
\hline & & Amoun & 37 & 100 \\
\hline
\end{tabular}

Data source: Student Observation Sheet before the Cycle

Student participation as a behavior that accompanies learning outcomes, it turns out that the data is the same as the learning outcome data in Table 1.

\section{Description of Cycle I Results \\ Planning}

Planning on the material of Congruence and Similarity to students in class IX SMP Negeri 1 Pulau Rakyat Asahan with various media to improve learning outcomes is as follows: 1) Prepare research tools, including: Learning implementation plans that include: basic competencies, learning outcomes, indicators, learning objectives, learning materials, learning methods, learning steps, tools and material resources, and assessment. Then make student observation sheets and make student learning results sheets; 2) Applying various learning media sequentially. Introducing forms of congruence and similarity to students starting with still image media, followed by graphic media, model media, and finally reality media.

Recognition of the forms of Congruence and Likeness through the media of still images, where the teacher draws the forms of Congruence and Similarity on the blackboard and introduces students to the names of each picture. Recognizing the forms of Congruence and Likeness through the media model, where the teacher shows the imitation forms of Congruence and Likeness, then groups the artificial objects into groups of forms of Congruence and Similarity. While introduction of congruence and congruence forms through reality media, the teacher shows the real objects of congruence and congruence forms, then classifies the original objects into groups of congruent and congruent forms; 3) Provide opportunities for students to answer verbally to questions about forms of congruence and congruence that have been introduced by students. This is with the intention of knowing the extent of student learning outcomes.

\section{Implementation}

The lesson plan that has been designed at the planning stage is fully implemented at this stage. Broadly speaking, the activities include the following: a) Opening lessons including: opening greetings, perceptions and motivation 
given to students; b) Core activity: delivering material forms of congruence and congruence with various learning media sequentially, namely as follows: 1) Still image media. Draw the Congruence and Similarity shapes on the board and introduce students to the names of each of the pictures. Learning forms of congruence and similarity using still image media; 2) Graphic media. Draw on the chalkboard, as well as write down names The congruence and congruence of the picture next to the picture. Then introduce it to students; 3 ) Media model. Students to group the imitation objects into groups of forms of congruence and congruence; and 4) Reality media. Shows tangible objects in the form of congruence and congruence, then groups these objects into groups of congruence and congruence forms. The closing activities include: making student learning outcomes sheets through formative questions, and closing greetings.

\section{Observation}

Observations were made from the beginning to the end of the learning process in Cycle I to record student participation including: student concentration, student enthusiasm, student responsibility, the courage of students asking questions, and the courage of students answering questions.

\section{Reflection}

After the student learning outcomes sheets were carried out through formative sheets in learning the forms of congruence and congruence with various learning media in Cycle I, data on student learning outcomes were obtained as recorded in Table 3. below.

Table 3. Data on Student Learning Outcomes in Cycle I

\begin{tabular}{|c|c|c|c|c|}
\hline No & Category & Score & Total Students & Percentage (\%) \\
\hline 1 & Very Good & $81-100$ & 6 & 16.22 \\
\hline 2 & Good & $61-80$ & 7 & 18.92 \\
\hline 3 & Pretty Good & $41-60$ & 18 & 48.65 \\
\hline 4 & Less Good & $21-40$ & 6 & 16.22 \\
\hline 5 & Not Good & $0-20$ & 0 & 0 \\
\hline & & Amoun & 37 & 100 \\
\hline
\end{tabular}

Data source: Student Result Sheet Cycle I

Based on the data in Table 3, it can be seen that there is a positive impact of actions in Cycle I by applying various media to learning forms of Congruence and Conformity. Before the cycle, none of the students scored (61-80) and (81-100). After the first cycle it turned out that it rose very sharply, students who got scores (61-80) $18.92 \%$ and (81-100) $16.22 \%$. The increase in learning outcomes indicates that the increasing acquisition of student learning outcomes in the categories above indicates the criteria for improving learning outcomes in this classroom action research. The increase in learning outcomes is also followed by an increase in student participation. From the observation sheet about student participation in class, the data is obtained in Table 4 below.

Table 4. Student Participation Data Cycle I

\begin{tabular}{|c|c|c|c|c|}
\hline No & Category & Score & Total Students & Percentage (\%) \\
\hline 1 & Very Good & $81-100$ & 6 & 16.22 \\
\hline 2 & Good & $61-80$ & 7 & 18.92 \\
\hline 3 & Pretty Good & $41-60$ & 18 & 48.65 \\
\hline 4 & Less Good & $21-40$ & 6 & 16.22 \\
\hline 5 & Not Good & $0-20$ & 0 & 0 \\
\hline & & Amount & 37 & 100 \\
\hline
\end{tabular}

Data source: Student Observation Sheet Cycle I

The student participation data in Table 4 is almost the same as the data on learning outcomes in cycle I in Table 3. Before the cycle, none of the students scored (61-80) and (81-100). After the first cycle, students who got a score (61-80) of $18.92 \%$ and (81-100) of $16.22 \%$. The improvement of learning outcomes forms of congruence and similarity for class IX students of SMP Negeri 1 Pulau Rakyat Asahan from pre-cycle to cycle I can be seen in Table 5 below. 
Table 5. Data on Pre-Cycle and I-Cycle Learning Outcomes

\begin{tabular}{|c|l|c|c|c|c|c|}
\hline \multirow{2}{*}{ No } & \multirow{2}{*}{ Category } & \multirow{2}{*}{ Score } & \multicolumn{2}{|c|}{ Pre Cycle } & \multicolumn{2}{c|}{ Cycle 1 } \\
\cline { 4 - 7 } & & & Total Students & Percentage (\%) & Total Students & Percentage (\%) \\
\hline 1 & Very Good & $81-100$ & 0 & 0 & 6 & 16.22 \\
\hline 2 & Good & $61-80$ & 0 & 0 & 7 & 18.92 \\
\hline 3 & Pretty Good & $41-60$ & 16 & 43.24 & 18 & 48.65 \\
\hline 4 & Less Good & $21-40$ & 21 & 56.76 & 6 & 16.22 \\
\hline 5 & Not Good & $0-20$ & 0 & 0 & 0 & 0 \\
\hline & & Amount & $\mathbf{3 7}$ & $\mathbf{1 0 0}$ & $\mathbf{3 7}$ & $\mathbf{1 0 0}$ \\
\hline
\end{tabular}

From Table 5, it is clear that there is an increase in learning outcomes between before the cycle and after cycle I. However, considering that there are still some students who get quite good learning outcomes with scores (41-60), there are even 21 students who get poor learning outcomes. both with a score (21-40), it is necessary to implement additional actions in Cycle II.

\section{Description of Cycle II Results \\ Planning}

Action planning in Cycle II is basically the same as action planning in Cycle I. However, there are additional actions in this II cycle, namely providing solutions to students whose learning outcomes are still not good or good enough to improve their criteria to be good or very good.

\section{Implementation}

The lesson plan that has been designed at the planning stage is fully implemented at this stage. Broadly speaking, the activities include the following: a) Opening lessons including: opening greetings, perceptions and motivation given to students; b) Core activity: delivering material forms of congruence and congruence with various learning media sequentially, namely as follows: 1) Still image media. Draw the Congruence and Similarity shapes on the board and introduce students to the names of each of the pictures. Learning forms of congruence and similarity using still image media; 2) Graphic media. Draw on the chalkboard, and write the name Congruence and Conformity of the picture next to the picture. Then introduce it to students; 3) Media model. Students to group the imitation objects into groups of forms of congruence and congruence; and 4) Reality media. Shows tangible objects in the form of congruence and congruence, then groups these objects into groups of congruence and congruence forms. The closing activities include: making student learning outcomes sheets through formative questions, and closing greetings.

\section{Observation}

Observations were made from the beginning to the end of Cycle II learning to record observations about student participation in participating in learning activities.

\section{Research Results and Reflections on Cycle II}

After taking the action in Cycle II, the student learning outcomes sheet obtained the data in Table 6. below.

Table 6. Data on Student Learning Outcomes in Cycle II

\begin{tabular}{|c|l|c|c|c|}
\hline No & Category & Score & Total Students & Percentage (\%) \\
\hline 1 & Very Good & $81-100$ & 22 & 59.46 \\
\hline 2 & Good & $61-80$ & 15 & 40.54 \\
\hline 3 & Pretty Good & $41-60$ & 0 & 0.00 \\
\hline 4 & Less Good & $21-40$ & 0 & 0.00 \\
\hline 5 & Not Good & $0-20$ & 0 & 0 \\
\hline \multicolumn{5}{|c|}{ Amount } \\
\hline
\end{tabular}

Data source: Student Result Sheet Cycle II

Based on the data in Table 6 above, it can be seen that there is a significant increase in learning outcomes when compared to cycle I. In cycle I, students who get a score (61-80) of $18.92 \%$ and (81-100) of $16.22 \%$. In cycle II, students who got scores (61-80) were $40.54 \%$ and scores (81-100) were $59.46 \%$. Moreover, after cycle II there were no more students who got scores (21-40) and (41-60). The significance of the increase in learning outcomes, in fact, is supported by the increase in student participation in cycle II. From the student observation sheet in cycle II, the data is obtained in Table 7. below. 
Table 7. Student Participation Data Cycle II

\begin{tabular}{|c|c|c|c|c|}
\hline No & Category & Score & Total Students & Percentage (\%) \\
\hline 1 & Very Good & $81-100$ & 22 & 59.46 \\
\hline 2 & Good & $61-80$ & 15 & 40.54 \\
\hline 3 & Pretty Good & $41-60$ & 0 & 0.00 \\
\hline 4 & Less Good & $21-40$ & 0 & 0.00 \\
\hline 5 & Not Good & $0-20$ & 0 & 0 \\
\hline \multicolumn{3}{|r|}{ Amount } & 37 & 100 \\
\hline
\end{tabular}

Data source: Student Observation Sheet Cycle II

The student participation data in Table 7 above is exactly the same as the data on student learning outcomes in Table 6. There are no more students participation is categorized as quite good. Everything increases in criteria of good and very good.

To find out the increase in student learning outcomes from before the cycle until after cycle I and cycle II, it can be seen in the inter-cycle learning outcomes data in Table 8 below.

Table 8. Data on Inter-cycle Student Learning Outcomes

\begin{tabular}{|c|l|c|c|c|c|c|c|c|}
\hline \multirow{2}{*}{ No } & \multirow{2}{*}{ Category } & \multirow{2}{*}{ Score } & \multicolumn{2}{|c|}{ Pre Cycle } & \multicolumn{2}{c|}{ Cycle 1 } & \multicolumn{2}{c|}{ Cycle 2 } \\
\cline { 4 - 9 } & & & Total Students & Percentage (\%) & Total Students & Percentage (\%) & Total Students & Percentage (\%) \\
\hline 1 & Sangat Baik & $81-100$ & 0 & 0 & 6 & 16.22 & 22 & 59.46 \\
\hline 2 & Baik & $61-80$ & 0 & 0 & 7 & 18.92 & 15 & 40.54 \\
\hline 3 & Cukup Baik & $41-60$ & 16 & 43.24 & 18 & 48.65 & 0 & 0.00 \\
\hline 4 & Kurang Baik & $21-40$ & 21 & 56.76 & 6 & 16.22 & 0 & 0.00 \\
\hline 5 & Tidak Baik & $0-20$ & 0 & 0 & 0 & 0 & 0 & 0 \\
\hline \multicolumn{3}{|c|}{ Amount } & 37 & 100 & 37 & 100 & 37 & 100 \\
\hline
\end{tabular}

Based on the data in Table 8 above, it can be concluded that the increasing student learning outcomes in the above categories from cycle to cycle indicate the criteria for improving learning outcomes. In other words, performance indicators from quantitative data can be achieved in cycle II, so there is no need to take action in the next cycle.

\section{Discussion}

The results of classroom action research in order to improve student learning outcomes in class IX SMP Negeri 1 Pulau Rakyat Asahan through exploration of Congruence and Likeness materials with various learning media, the following discussion can be carried out: 1) In general, the increasing student learning outcomes in the above categories of the cycle to the cycle shows the criteria for improving learning outcomes. And the increase in student participation from cycle to cycle shows an increase in positive attitudes both in terms of quality and quantity as an indicator of positive learning improvement; 2) Improved learning outcomes in the Congruence and Conformity material, which in this case is marked by an increase in student learning outcomes and student participation in class; began to appear evident from before cycle to cycle I, and more markedly the increase in learning outcomes of the cycle I to the cycle II. Where in cycle II all student learning outcomes achieved good and very good criteria, and was followed by an increase in student participation who also all achieved good and very good criteria; 3) Learning outcomes as a student activity in an effort to gain knowledge, skills and positive values by utilizing various sources to learn effectively. In other words, learning outcomes are an effective learning process.

According to Badru Zaman, et al., (2008), one of the functions of learning media is to improve the quality of the learning process. So by applying various learning media, in this case applying still image media, graphic media, model media, and reality media in learning material forms of congruence and congruence, it is truly proven. This means that various learning media as one of the effective learning resources actually function to improve student learning outcomes.

The same thing was also conveyed by Wulandari (2017), that the objects of Congruence and Similarity are abstract, but they are a fact that Congruence and Likeness are very important aspects of mathematics and play a role in life. Congruence and congruence become material that wants to be known fundamentally and fundamentally for the development of mathematics itself and the development of human thinking abilities logically. One of the goals of teaching Congruence and Similarity in schools is to develop logical thinking skills. The basic objective is to give students the opportunity to further analyze the world in which they live and to provide a foundation in the form of concepts and terms needed at the next level of education from an early age. 


\section{Conclusions}

From the results of the description and discussion above, several conclusions can be drawn, including:

1). In the Pre-Cycle, the unfavorable category with scores (21-40) was obtained by 21 students (56.76\%), and in the good enough category with scores (41-60) obtained by 16 students (43.24\%).

2). In Cycle I, the unfavorable category with scores (21-40) was obtained by 6 students $(16.22 \%)$, the category was quite good with scores (41-60) obtained by 18 students (48.65\%), Good category with scores (61-80) obtained by 7 students $(18.92 \%)$, and very good categories with scores (81-100) obtained by 6 students $(16.22 \%)$.

3). In Cycle II, the good category with a score (61-80) was obtained by 15 students $(40.54 \%)$ and the very good category with a score (81-100) was obtained by 22 students $(59.46 \%)$.

\section{Bibliography}

Amirul Mukminin. 2011. Learning Evaluation PAUD. Semarang State University. Semarang.

Arikunto. 2006. Research Procedure A Practice Approach. Rineka Cipta. Jakarta.

Gultom Fransiskus, et al., 2018. Performance Evaluation in Management Implementation Through Work Ethos, Work Motivation, and Work Discipline on STKIP Riama Medan. Journal of Education and Practice. ISSN 2222-1735 (Paper) ISSN 2222-288X (Online). Vol.9, No.13, 2018. Page. 22-27. https://www.iiste.org/Journals/index.php/JEP/article/view/42374/43639.

Gultom Fransiskus, et al., 2019. The Effect of Transformational Leadership on Work Satisfaction and Performance in STKIP Riama Medan. Journal of Education and Practice. ISSN 2222-1735 (Paper) ISSN 2222-288X (Online). Vol.10, No.18, 2019 DOI: 10.7176/JEP. Page. 29-33. https://www.iiste.org/Journals/ index.php/JEP/article/view/42374/43639.

Gultom Fransiskus, et al., 2020. Implementation of Transformational Leadership on Lecturer Satisfaction and Performance in FKIP Darma Agung University Medan. Journal of Education and Practice. ISSN 22221735 (Paper) ISSN 2222-288X (Online). Vol.11, No.19, 2020. Page. 65-69. https://www.iiste.org/ Journals/index.php/JEP/article/view/42374/43639.

Gultom Fransiskus, et al., 2020. Performance Evaluation in Management Implementation Through Work Ethic, Work Motivation, and Work Discipline in FKIP Darma Agung University Medan. Journal of Education and Practice. ISSN 2222-1735 (Paper) ISSN 2222-288X (Online). Vol.11, No.30, 2020. Page. 4450.https://www.iiste.org/Journals/index.php/JEP/article/view/54473/56286

Hamimah, H., Zuryanty, Z., Kenedi, A. K., dan Nelliarti, N., 2019. The Development of the 2013 Student Curriculum Book Based on Thinking Actively in Social Context for Elementary School Students. Al Ibtida: Jurnal Pendidikan Guru MI, 6(2), 159-176.

Hendri, S., Kenedi, A. K., Anita, Y., Habibi, M., dan Akmal, A. U., 2019. Validation of Discovery LearningBased to Increase The Ability Of Elementary Students Problem Solving Skills. In Journal of Physics: Conference Series (Vol. 1318, No. 1, p. 012109). IOP Publishing.

Kunandar, S. P., 2012. Easy Steps for Classroom Action Research as Teacher Professional Development. PT Raja Grafindo Persada. Jakarta.

Musanna, A., 2017. Indigenization of Education: The rationality of the revitalization of Ki Hadjar Dewantara's educational praxis. Journal of Education and Culture, 2(1), 117-133.

Pane, A., and Dasopang, M. D., 2017. Learning and Learning. Fitrah: Journal of Islamic Studies, 3(2), 333-352.

Ronowijayan Ponorogo. Journal of Basic Education, 1(2), 26-36.

Sanjaya Wina. 2008. Planning and Design of Learning Systems. Kencana Prenada Media Group. Jakarta.

Sofyan, N. H., 2016. The Effectiveness of Learning Quiz Team Methods in Computer Logic Subjects in terms of Student Learning Motivation. Journal of Informatics and Science Education, 4(1).

Susilana and Cepi Riyana. 2007. Learning Media, Nature, Development, Utilization, and Assessment, Effective Learning Series. Raja Grafindo Persada. Jakarta.

Wulandari, Y., Wahyuni, A., and Elisa, E., 2017. The Effectiveness of the Quiz Team Type Active Learning Method on Student Learning Outcomes on Simple Aircraft Subjects. Scientific Journal of Physics Education Students, 2(2), 202-206. 